\section{ANGLO-AMERICAN CO-OPERATION IN SCIENTIFIC RESEARCH}

\section{BY PRESIDENT JAMES B. CONANT,} For. Mem. R.S.

$\mathrm{T}$ HE following address by President James B. Conant, of Harvard University, was arranged to be given on September 26 before the Conference on Soience and World Order, under the auspices of the British Association for the Advancement of Science, in London. The address was made on a record in Washington and flown across the Atlantic for rebroadcast to the Conference. Unfortunately, it failed to arrive, but the following copy has recently reached us.

I assume that through the United States Ambassador, Mr. Winant, you have asked me to address you because of the fact that I am chairman of the National Defense Research Committee, an arm of the United States Government. In that capacity, it is perhaps fitting that I should have something to say about the mobilization of science in the United States and the co-operation of British and American men of science for the war effort. On the other hand, many things that $I$ have said as a private citizen of the United States concerning the foreign policy of my country would be entirely inappropriate in this address. To some of you my views are known. I can only say that I hold them with greater conviction every day. Many of my fellow men of science and academic colleagues on this side of the water are of the same opinion-others have disagreed. That a great debate has raged in the United States about the extent and nature of our participation in the war against Hitler will be no surprise to a British audience. For if I read your recent history rightly, it was not a matter of weeks or even months, but rather of years before the citizens of your country were able to resolve the deep conflict between the ideal of peace and the ideal of freedom, between their hatred of war and their hatred of the Nazi philosophy of tyranny and fear. For I take it these were the elements which determined the development of your own foreign policy before the War.

But in one matter I can brush aside all harassing ambiguities. On one point all American men of science are agreed. They unite in saluting the bravery of the British nation; they applaud unanimously your gallant stand. Moreover, as scientific workers they are proud of the vital parts their fellow-workers of Great Britain are playing in the struggle now in progress. They realize, though often only dimly, that history will surely record this heroic struggle as a defence against overwhelming odds not only of Great Britain but also of individual liberty throughout the world.
In June 1940 the first realization of a world crisis aroused the United States. Amidst violent debates on foreign policy, a vast programme of rapid rearmament was initiated. As to the necessity of producing at top speed a great quantity of instruments of war there could be but one opinion. In these circumstances it was essential to mobilize the scientific talent of our country with all haste. The National Defense Research Committee, with Dr. Vannevar Bush as chairman, was then ereated by Presidential order. Its task was not advisory, for the scientific advisory bodies of the Government had long been in existence. The National Academy of Science, a parallel of your Royal Society, has by Congressional charter the duty of advising the Federal Government on scientific matters. The National Research Council, a creation of the Academy, has functioned effectively to that end for many years and still continues to play an active part, particularly in the field of medical research. What was needed was not another advisory body but an executive agency capable of bringing available scientific talent as soon as possible in touch with the army and navy; an executive agency to speed up the scientific research on instrumentalities of war by drawing on the existing laboratory facilities of the whole country. This was the function the National Defense Research Committee was created to fulfil.

The new Committee was composed of six civilians together with a representative of the Secretary of War and a representative of the Secretary of the Navy. Rather than establish any large organization of its own, the National Defense Research Committee decided to use its available appropriations through contracts with universities and industrial firms which would carry on specific research and development on secret matters pertaining to modern warfare. Through various sub-committees or divisions, each headed by a Committee member, the work was soon divided. To my lot fell chemistry, to Prof. K. T. Compton, of Massachusetts Institute of Technology, fell one branch of physics, to Jewett and Tolman were assigned still others. Liaison officers from the Army and the Navy were attached to the various sub-committees. In this way the men of science brought into the new work were kept in active touch with members of the Armed Forces.

During the past year, more than ten million dollars have been spent through 270 contracts placed with 47 different universities and technical colleges and 153 contracts placed with thirty-nine industrial firms. Needless to say, great precautions have been necessary to insure the secrecy of the work. No man has been brought into the organization either as a member of a sub-committee or as a contractor without the approval of 
the Army and the Navy. Great care has also been taken to ensure secrecy in the placing of the contracts either with academic workers or industrial firms.

In both physics and chemistry the effort has been to distribute so far as possible the problems to different investigators throughout the country. In this way, during the initial year at least, the normal functions of our universities were, so far as possible, undisturbed. In a few cases the nature of the work has made such an arrangement quite impossible. In one case in particular, the Radiation Laboratory at the Massachusetts Institute of Technology, it was essential that a large group of physicists should be assembled to work on a highly confidential and important subject with the greatest possible speed. Therefore, more than 150 different physicists from twenty-five different universities in all parts of the country have been brought together to work towards a common goal. We estimate that approximately a thousand scientific workers, ranging all the way from senior professors to young research workers, are now at work in one way or another in academic institutions under contracts with the National Defense Research Committee. In addition, more than seven hundred scientific workers of the same grades are at work in industrial firms in connexion with the contracts which have there been placed. As in your own country, we have found that the nature of the problems in this War are such that physieists and certain types of engineers are in greater demand than chemists. Indeed, it would appear from a survey that has recently been made that probably 75 per cent of the more distinguished research physicists of the country (those starred in the "American Men of Science") who are available are now at work on war problems. I hazard the opinion that it will be only a few months before the remaining 25 per cent are equally involved.

The success of the undertaking has been due in no small measure to the effectiveness of Dr. Vannevar Bush, both as a man of science and as an administrator. Dr. Bush was the chairman of the Committee during the first year of its existence and shouldered the responsibilities for the enormous task. Three months ago, by order of the President, he was made director of a newly created Office of Scientific Research and Development. In this capacity Dr. Bush was charged not only with many of the responsibilities which he had formerly carried as chairman of the National Defense Research Committee, but with the further task of co-ordinating scientific research on medical problems affecting national defence. Most important of all, he has the charge of co-ordinating, and where desirable, supplementing the scientific research activities carried on by the Departments of War and Navy and other agencies of the Federal Government. The National Defense Research Committee now becomes a part of the new Office of Scientific Research and Development, and I, as the new chairman, am responsible to Dr. Bush.

Parallel to our Committee is a newly formed one on medical research, of which Prof. Alfred N. Richards is chairman. Together these two Committees will be the main instruments which the Office of Scientific Research and Development will use to carry out the task entrusted to it by order of the President of the United States.

Such, in brief, is the organization which has been created to bring about the rapid mobilization of scientific talent in the United States to aid the Armed Forces of the Federal Government. Those who are interested in problems of organization and administration will note that the scheme is both flexible and temporary. It is clearly designed to last only during the period of national emergency. No new permanent organizations are created, no new Government laboratories are built or staffed, no large administrative offices are established. Rather a method was devised by which with all speed possible the available scientific talent and available laboratories of the country could be used to supplement the already existing research establishments of the Army and the Navy.

One of the happiest results of the past year's labours has been the ever-increasing AngloAmerican co-operation in scientific fields. This was at first made possible on our side of the water by the National Defense Research Committee ; it is now a function of the new Office of Scientific Research and Development. The Executive Order which established this office with Dr. Bush at its head provided that the Director should initiate and support such scientific research as may be requested by the Government of any country the defence of which the President deems vital to the defence of the United States under the terms of the Lease-Lend Act of March 11, 1941. As many of you know, we have had in London since last March American scientific liaison officers, Mr. Hovde and Mr. Lewis. It was my privilege to come to England with Mr. Hovde and to initiate the exchange of research information on instrumentalities of war. From the first moment of our arrival, we met a cordiality and openness of welcome that made evident your whole-hearted interest in co-operation. I trust the British representatives in Washington have formed a similar opinion of the American attitude.

After more than six months of work our interchanges of information and of workers have yielded results of considerable importance. I believe that we on our side of the Atlantic have contributed something to your great effort, and I hope and pray 
that our contribution before many months are past will be of the first order of importance; for I know I am speaking for my fellow-workers in the National Defense Research Committee when I say that nothing would give us more satisfaction than to feel that through our work we had contributed directly to the effectiveness of the war effort. Our eagerness to help can scarcely be over-estimated; may the future demonstrate that our capacities have been equal to our desires!

I cannot conclude without referring briefly to what must be to some extent in everyone's mind at this Conference-the world we are going to live in after the War is over. It is not for me to outline a world order or even to express views on Anglo-American policy. But no intelligent man who on one hand loves peace, and on the other places the highest value on individual liberty, can doubt that without some form of co-operation between our two countries no peace worth fighting for can be established. Similarly, no intelligent man who consults his head as well as his heart can fail to note great obstacles that stand in the way of effective co-operation and collaboration. It should be the duty of all trained thinkers, particularly men of science, on both sides of the water, to study these obstacles coolly and impar. tially. For only by knowing their nature may we hope to overcome them. Only by dispassionate study may we hope to reduce these barriers.

I say particularly men of science, for they realize more than many others the potentialities that lie hidden in the future. Men of science realize as many cannot the extent to which modern technology has diminished effective distances around this planet. They know; too, that the end of this revolution in transportation is not yet in sight. The world contracts before their eyes. To them dreams of new adventures and new conquests of the material universe wait for realization only on the sustained labour of free men. To-day, the men of science of Great Britain and the United States are working almost as one group with the purpose of improving instruments of war. Is it fantastic to hope that in the not too distant future the men of science of all free countries may be joined in effective action to improve, not instruments of war, but those of peace? I like to see in the present scientific liaison that runs through the centre of London, Ottawa and Washington a hopeful omen of a long period marked by the friendliest relations between the British Commonwealth of Nations and the United States. If this be so, our work foreshadows a time when professional talent in many diverse societies of free men will strive for effective co-operation to the end that we and our children may walk boldly along the paths of liberty and peace.

\section{AGRICULTURE AFTER THE WAR}

\author{
By SIR JOHN RUSSELL, F.R.S.
}

Director, Rothamsted Experimental Station

THE invention of the submarine has profoundly affected the development of British agriculture, bringing it out of its accustomed obscurity into a very high position both in the War of 1914-18 and in this War. British peace-time dietary is more varied and effective than that of any other country in Europe, but it requires so much land for its production-on the average some 1.6 acres per person-that the total area of agricultural land suffices only to provide 40 per cent of the nation's food. The remaining 60 per cent has to be imported, and it was brought in from almost all quarters of the world. This method of feeding the nation postulates peace and the smooth working of international trade, and it breaks down in war-time. Home production then becomes much more important, and the national dietary is changed so as to make less call on the land; in place of the 1.6 acres of peace-time, the aim is to get nearer to the $1 \cdot 1$ acres that suffice for the German dietary. Further, there is widespread recognition that British agriculture is a major industry, and that unless it is sufficiently prosperous to attract and retain a vigorous and intelligent body of farmers and farm workers, there will always be trouble in the country-side. Under the chastening influence of war, politicians and writers become very penitent about their past attitude to agriculture and full of good resolves for the future.

We are somewhat in this position now, and we passed through the same phase in the War of 1914-18. Then it was resolved that British agriculture really should be developed, and wages boards were set up to impose a minimum wage which would ensure the workers' efficiency and do away with the hardships which some of them had suffered. Prices were to be at such a level that these wages could be paid.

There arose the difficulty that has always proved oppressive and for which no satisfactory remedy has yet been put into operation. Agricultural produce can be raised very cheaply by peasants in almost any country in Europe and by farmers using ranching or other 'extensive' methods in some of the new countries, and trading organizations can collect it and bring it to our markets at very cheap rates. The peasant is, of course, poorly paid, but his standards are low, and the 'extensive' methods may be harmful and even destructive to the soil ; but they answer for a time. In other producing countries where sound intensive methods were used, special arrangements were often 